\title{
FLORISTIC COMPOSITION OF WEEDS IN PADDY FIELDS IN MAHENDRANAGAR, NEPAL
}

\author{
M.D. Bhatt, A. Tewari ${ }^{1}$ and S.P. Singh ${ }^{2}$ \\ Department of Botany \\ Siddhanath Science Campus, Mahendranagar, Nepal \\ Email: bhattmd@rediffmail.com \\ ${ }^{1}$ Department of Forestry, Kumaun University, Nainital, India \\ ${ }^{2}$ Department of Botany, Kumaun University, Nainital, India
}

\begin{abstract}
Field experiments were conducted during 2004 and 2005 in paddy fields to evaluate the floristic composition of weeds, in lowland and upland areas of Mahendranagar, Nepal. A total of 61 weed species belonging to 42 genera and 23 families were recorded. Of the 23 families, Cyperaceae was the largest (13 spp.), followed by Poaceae (11 spp.), Euphorbiaceae (4 spp.), Amaranthaceae, Commelinaceae and Asteraceae ( 3 spp. each), Polygonaceae ( 2 spp.) and one species each belonged to Apiaceae, Acanthaceae, Alismataceae, Pontederiaceae, Leguminosae, Convolvulaceae, Eriocaulaceae, Marsileaceae, Malvaceae, Oxalidaceae, Onagraceae, Parkeriaceae, Portulaceae, Rubiaceae and Verbenaceae. The number of weed species was higher in upland (55) when compared with the lowland sites (48). On the basis of Importance Value Index (IVI) dominating weed species in paddy fields were: Fimbristylis miliacea (13.4), Lindernia oppositifolia (13.2), Eleocharis atropurpurea (13.1), Ageratum conyzoides (13.0), Cyperus iria (13.0), Echinochloa crus-galli (11.9), Ischaemum rugosum (11.7), Echinochloa colona (11.4), Cyperus difformis (11.1) and Schoenoplectus juncoides (11.0). Besides dicots and monocots, two species of pteridophytes (Ceratopteris thalictriodes and Marsilea minuta) were also recorded in lowland paddy fields.
\end{abstract}

Key words: Paddy, weeds, upland, lowland, IVI.

\section{INTRODUCTION}

Paddy is the most important staple crop of Nepal. The weeds that abound along with the paddy crops further affect the low agriculture production because of limited area for cultivation. There is a need to assess the loss in paddy crop production because of these unwanted, useless and persistent weed species. Further to restrict the loss in paddy biomass it is necessary to reduce their soil seed bank and reduce their population in the coming year by poor farmers. The reduction in paddy yield due to weed composition ranges from 9-51\% (Mani et al. 1968). Grain yield was drastically reduced if paddy is not weeded out during early growth stages. In Nepal, weed surveys in paddy fields have received very little attention in comparison to other southeastern countries of Asia (Moody 1989). Species composition (Dangol et al. 1986, Ranjit 1998, Dangol 2002, Thapa and Jha 2002) of paddy field weeds was studied in some 
parts of Nepal. The present study was undertaken to record and analyze the weed species composition in upland broadcasting and lowland transplanting paddy fields of Mahendranagar, in Far Western Region of Nepal.

\section{MATERIALS AND METHODS}

The field experiments were conducted during rainy season of 2004 and 2005 at farmers' agricultural fields in Mahendranagar (28 $32^{\prime} \mathrm{N}$ and $80^{\circ} 33^{\prime} \mathrm{E}$ and $185-300 \mathrm{~m}$ amsl), in two study sites, i.e., upland in which irrigation facility lacks and a broadcasted system was applied on the basis of traditional methods adopted by the farmers, and in lowland, which is facilitated with irrigation and transplanted system was applied. The soil was silty clay in texture and high in fertility with $6.2-6.5 \mathrm{pH}$. The paddy was broadcasted in early June with the arrival of pre-monsoon at upland site. At lowland site 29 days old seedlings were transplanted in early-July on $5 \mathrm{~m}$ x $5 \mathrm{~m}$ sized plots in randomised block design (RBD). From the date of paddy cultivation to harvest time, weed species were observed for floristic study. All the collected weeds were identified with the relevant literature and finally confirmed with the help of authentic specimens at National Herbarium and Plant Laboratories, Godawari, Lalitpur, Nepal. For the vegetational analysis of weeds, ten quadrats of $1 \mathrm{~m}$ $\mathrm{x} 1 \mathrm{~m}$ were placed for density, frequency, and abundance, recorded as per Misra (1968). The weeds with higher density and Importance Value Index (IVI) were considered as dominant weeds.

\section{RESULTS AND DISCUSSION}

Of the Sixty one species of weeds recorded in the paddy fields, 29 species were dicotyledons, 30 monocotyledons (15 grasses and 15 sedges species) and 2 pteridophytes (Table 1). Out of the total weed species, 55 were recorded at upland site and 48 at lowland site. At upland site there were
$49.1 \%$ dicot species and $50.9 \%$ monocot species, and at lowland site, $47.9 \%$ were dicots and $47.9 \%$ monocot species as well, and $4.2 \%$ pteridophytes (Table 2). The dominance of monocots over dicots at upland site in present investigation was similar to the findings of Satyanarayan (1962), and Thapa and Jha (2002). The dominance of grasses and sedges in the present study corresponds to the findings of Thapa and Jha (2002) and Dangol et al. (2002). Two species of pteridophytes (Ceratopteris thalictroides and Marsilea minuta) were recorded at lowland transplanted paddy fields of Mahendranagar. Similar results have been reported by Dangol et al. (1986) from the paddy fields of Rampur, Chitwan, Nepal. Recorded species belonged to 23 families: Cyperaceae (13 spp.), Poaceae (11 spp.), Scrophulariaceae (7 spp.), Euphorbiaceae (4 spp.), Amaranthaceae, Commelinaceae and Asteraceae (3 spp. each), Polygonaceae (2 spp.) and one species each belonged to Apiaceae, Acanthaceae, Alismataceae, Pontederiaceae, Leguminosae, Convolvulaceae, Eriocaulaceae, Marsileaceae, Malvaceae, Oxalidaceae, Onagraceae, Parkeriaceae, Portulaceae, Rubiaceae and Verbenaceae.

The total density of weeds was 240 individuals $\mathrm{m}^{-2}$ at upland site and 208 individuals $\mathrm{m}^{-2}$ at lowland site revealing that paddy field of upland site had more weeds than the paddy field of lowland site. On the basis of density and IVI, 12 weed species dominated both the study sites. The maximum weed density was recorded for Fimbristylis miliacea $\left(16.9 \mathrm{~m}^{-2}\right.$, at upland site) and Eleocharis atropurpurea $\left(15.6 \mathrm{~m}^{-2}\right.$, at lowland site) (Table 1).

Thus, on the basis of density and importance value index, 12 species of weeds recorded as dominant in paddy fields at upland and lowland sites. Among them Cyperus iria, Echinochloa colona, Echinochloa crus-galli, Sagittaria guayanensis, Cyperus difformis, Ischaemum 
rugosum, Eleocharis atropurpurea and Cynodon dactylon are reported as being the important weeds of paddy fields in the world by Holm et al. (1977). Of the 12 most important weeds, 8 were common to both upland and lowland sites. Of them Ageratum conyzoides, which had the maximum density at upland site, had poor density at lowland site.

Table 1. Species, families average density (ind. $/ \mathrm{m}^{2}$ ) and Importance Value Index (IVI) of weeds in upland and lowland paddy fields of Mahendranagar, Nepal.

\begin{tabular}{|c|c|c|c|c|c|}
\hline \multirow[t]{2}{*}{ Weed species } & \multirow[t]{2}{*}{ Family } & \multicolumn{2}{|c|}{ Upland } & \multicolumn{2}{|c|}{ Lowland } \\
\hline & & Density & IVI & Density & IVI \\
\hline Ageratum conyzoides $\mathrm{L}$. & Asteraceae & 16.1 & 13.0 & 5.0 & 6.5 \\
\hline Alternanthera sessilis (L.) DC. & Amaranthaceae & 6.9 & 10.2 & 7.1 & 11.3 \\
\hline Alysicarpus vaginalis (L.) DC. ${ }^{\#}$ & Leguminosae & 1.9 & 3.0 & - & - \\
\hline Amaranthus spinosus L. ${ }^{\#}$ & Amaranthaceae & 0.7 & 1.5 & - & \\
\hline Amaranthus viridus L." & Amaranthaceae & 1.9 & 2.7 & - & - \\
\hline Brachiaria ramosa (L.) Stapf. ${ }^{\#}$ & Poaceae & 2.7 & 2.0 & - & - \\
\hline Caesulia axillaris Roxb. & Asteraceae & 2.4 & 2.9 & 2.7 & 4.8 \\
\hline Centella asiatica (L.) Urb & Apiaceae & 1.6 & 3.2 & 2.4 & 4.8 \\
\hline Ceratopteris thalictroides (L.) A. Brongu* & Parkeriaceae & - & - & 2.2 & 3.2 \\
\hline Commelina benghalensis Blume $\mathrm{e}^{\#}$ & Commelinaceae & 2.4 & 4.7 & - & - \\
\hline Commelina paludosa Blume & Commelinaceae & 1.5 & 3.7 & 3.2 & 4.2 \\
\hline Cynodon dactylon (L.) Pers. & Poaceae & 9.3 & 9.5 & 6.5 & 10.0 \\
\hline Cyperus corymbosus Rottb. & Cyperaceae & 1.7 & 3.2 & 2.9 & 5.0 \\
\hline Cyperus difformis $\mathrm{L}$. & Cyperaceae & 2.4 & 4.1 & 9.1 & 11.1 \\
\hline Cyperus esculentus $\mathrm{L}$. & Cyperaceae & 2.6 & 3.6 & 2.9 & 4.1 \\
\hline Cyperus halepens $\mathrm{L}$. & Cyperaceae & 5.1 & 6.3 & 2.6 & 3.3 \\
\hline Cyperus iria $\mathrm{L}$ & Cyperaceae & 15.1 & 12.5 & 12.1 & 13.0 \\
\hline Cyperus kyllingia Endl. & Cyperaceae & 2.1 & 4.6 & 1.9 & 4.9 \\
\hline Cyperus rotundus $\mathrm{L}$. & Cyperaceae & 3.9 & 4.7 & 3.7 & 5.9 \\
\hline Cyperus sanguinolentus Vahl & Cyperaceae & 1.9 & 2.7 & 1.8 & 2.3 \\
\hline Dactyloctenium aegypticum (L.) Gaertn. ${ }^{\#}$ & Poaceae & 2.7 & 4.2 & - & - \\
\hline Digitaria sanguinalis (L.) Scop. ${ }^{\#}$ & Poaceae & 2.9 & 6.4 & - & - \\
\hline Dopatrium junceum (Roxb.) F. Halminton ex Bentham* & Scrophulariaceae & - & - & 3.8 & 5.4 \\
\hline Echinochloa colona (L.) Link & Poaceae & 7.0 & 10.2 & 6.7 & 11.4 \\
\hline Echinochloa crus-galli (L.) Beauv. & Poaceae & 6.8 & 10.1 & 7.8 & 11.9 \\
\hline Eclipta prostrata ( L.) L. & Asteraceae & 5.8 & 9.7 & 2.8 & 5.4 \\
\hline Eleocharis atropurpurea (Retz.) Presl & Cyperaceae & 16.0 & 13.1 & 15.6 & 11.7 \\
\hline Elusine indica (L.) P. Beauv. & Poaceae & 2.1 & 2.8 & 2.0 & 3.1 \\
\hline Eragrostis tenella (Retz.) Stapf. ${ }^{\#}$ & Poaceae & 1.3 & 2.4 & - & - \\
\hline Eragrostis uniloides (Retz.) Nees ex Steud. & Poaceae & 2.2 & 2.8 & 2.4 & 3.3 \\
\hline Eriocaulon cinereum $\mathrm{R}$. Br. & Eriocaulaceae & 6.1 & 6.1 & 3.8 & 5.4 \\
\hline Euphorbia hirta L. & Euphorbiaceae & 3.1 & 3.8 & 2.9 & 4.1 \\
\hline ECOPRINT VOL 16, 2009 & & & & & 17 \\
\hline
\end{tabular}


Euphorbia parviflora L.

Evolvulus nummularis (L.) L.

Fimbristylis dichotoma (L.) Vahl

Fimbristylis miliacea (L.) Vahl

Fimbristylis ovata (N.L. Burman) Kern"

Hedyotis corymbosa (L.) Lam.

Hygrophila auriculata (Schumach) Heine*

Ischaemum rugosum Salisb.

Lindernia antipoda (L.) Alston

Lindernia ciliata (Colsm.) Pennell ${ }^{\#}$

Lindernia oppositifolia (L.) Mukerjee

Lindernia procumbens (Krock.) Borbas

Lindernia viscosa (Hornem) Boldigh

Lippia nodiflora (L.) Rich

Ludwigia perennis $\mathrm{L}$.

Marsilea minuta L. *

Mecardonia procumbens (Mill.) Small

Monocharia hastata (L.) Solms. *

Murdania nudiflora (L.) Brenan

Oxalis corniculata L. $^{\text {\# }}$

Persicaria barbata (L.) Hara

Phyllanthus urinaria L.

Phyllanthus varigatus $\mathrm{G}$. Frost

Polygonum plebejum R. Br.

Portulaca oleracea L.

Sagittaria guayanensis Kunth*

Schoenoplectus juncoides (Roxb.) Palla

Setaria pumia (Poiret) Romer \& Schulte ${ }^{\#}$

Sida acuta Brum. f. ${ }^{\#}$

Total 61 species

\begin{tabular}{|c|c|c|c|c|}
\hline Euphorbiaceae & 1.5 & 3.5 & 1.8 & 3.6 \\
\hline Convolvulaceae & 2.8 & 4.3 & 3.2 & 4.2 \\
\hline Cyperaceae & 7.9 & 8.2 & 3.3 & 5.2 \\
\hline Cyperaceae & 16.9 & 13.4 & 11.5 & 11.7 \\
\hline Cyperaceae & 1.5 & 3.5 & - & - \\
\hline Rubiaceae & 1.8 & 5.0 & 1.9 & 4.5 \\
\hline Acanthaceae & - & - & 1.3 & 2.0 \\
\hline Poaceae & 6.9 & 10.2 & 7.2 & 11.7 \\
\hline Scrophulariaceae & 7.2 & 6.7 & 3.7 & 5.9 \\
\hline Scrophulariaceae & 0.9 & 1.6 & - & - \\
\hline Scrophulariaceae & 16.2 & 13.2 & 4.6 & 6.3 \\
\hline Scrophulariaceae & 10.6 & 10.8 & 3.2 & 5.6 \\
\hline Scrophulariaceae & 3.3 & 4.5 & 2.8 & 3.4 \\
\hline Verbenaceae & 1.4 & 4.3 & 3.2 & 5.6 \\
\hline Onagraceae & 3.8 & 5.6 & 6.6 & 10.9 \\
\hline Marsileaceae & - & - & 3.2 & 5.1 \\
\hline Scrophulariaceae & 2.6 & 3.6 & 2.1 & 3.7 \\
\hline Pontederiaceae & - & - & 2.7 & 4.9 \\
\hline Commelinaceae & 1.9 & 3.9 & 3.1 & 4.8 \\
\hline Oxalidaceae & 1.3 & 2.9 & - & - \\
\hline Polygonaceae & 1.1 & 1.7 & 2.4 & 4.8 \\
\hline Euphorbiaceae & 1.4 & 3.1 & 2.1 & 3.7 \\
\hline Euphorbiaceae & 1.9 & 4.5 & 2.5 & 4.8 \\
\hline Polygonaceae & 1.9 & 3.9 & 1.3 & 3.3 \\
\hline Portulacaceae & 1.5 & 2.2 & 3.9 & 6.6 \\
\hline Alismataceae & - & - & 8.1 & 10.6 \\
\hline Cyperaceae & 3.7 & 5.2 & 8.4 & 11.0 \\
\hline Poaceae & 1.1 & 1.2 & - & - \\
\hline Malvaceae & 0.7 & 1.5 & - & - \\
\hline 23 families & 240.0 & 300 & 208.0 & 300 \\
\hline
\end{tabular}

${ }^{\#}$ Species occurring only at upland site, $*$ Species occurring only at lowland site, - = absent.

Table 2. Floristic analysis of weed species in different fields of paddy (Values in parentheses are percentage of total).

\begin{tabular}{lcccccc}
\hline Plant groups & \multicolumn{2}{c}{ Upland (broadcasted paddy) } & \multicolumn{2}{c}{ Lowland (transplanted paddy) } \\
& Family & Genera & Species & Family & Genera & Species \\
\hline Dicotyledons & $14(77.8)$ & $20(55.6)$ & $27(49.1)$ & $12(60.0)$ & $18(51.4)$ & $23(47.9)$ \\
Monocotyledons & $4(22.2)$ & $16(44.4)$ & $28(50.9)$ & $6(30.0)$ & $15(42.9)$ & $23(47.9)$ \\
Pteridophytes & - & - & - & $2(10.0)$ & $2(5.7)$ & $2(4.2)$ \\
Total & $18(100.0)$ & $36(100.0)$ & $55(100.0)$ & $20(100.0)$ & $35(100.0)$ & $8(100.0)$ \\
\hline
\end{tabular}


From the two years observations, it was found that weed growth occurs within forty one days after paddy sowing/planting and they may propagate by seeds and propagules or by both. The perennial weeds create the most serious problem in paddy fields. Major weeds produce a large number of seeds, which may remain in soil and serve as soil seed bank for the next cropping season. It can be emphasized that major weeds should be controlled at proper time to check reduction in paddy yield, and they must be removed before flowering and fruiting to reduce the production of seeds that remain as soil seed bank for the following years.

\section{ACKNOWLEDGEMENTS}

MDB is thankful to Mr. D.D. Joshi, Campus Chief, S.N. Science Campus (T.U.), Mahendranagar for providing necessary facilities, and to University Grants Commission, Kathmandu, Nepal for providing research fellowship, to Institute of Science and Technology, T.U. for granting study leave and to staff members of KATH herbarium, Godawari, Nepal for identification of plant species.

\section{REFERENCES}

Dangol, D.R. 2002. A study of weed flora in some crop fields of Chitwan, Nepal. J. Nat. His. Mus. (TU) 21:129-135.

Dangol, D.R., S.B. Gurung and I. Bhattarai. 1986. Lowland rice weeds at the agronomy farm of
IAAS, Rampur, Chitwan, Nepal. J. Inst. Agric. Anim. Sci. (TU) 7:1-11.

Holm, G.L., D.L. Plucknett, J.V. Pancho and J.P. Herberger. 1977. The World's Worst Weeds: Distribution and Biology. East west center press, Honolulu, Hawaii, USA, 609 pp.

Mani, V.S., K.C. Gautam and T.K. Chakraberty. 1968. Losses in crop yield in India due to weed growth. PANS 42:142-158.

Misra, R. 1968. Ecology Workbook. Oxford and IBH Publishing Company, New Delhi, India.

Moody, K. 1989. Weeds Reported in South and South East Asia. International Rice Research Institute, Manila, Philippines. 442 pp.

Ranjit, J. D. 1998. Weeds and weed management in the Rice-Wheat system. In: Proc. of the Rice-Wheat Research Workshop. (eds.) Hobbs, P.R. and N.P. Rajbhandari. Nepal Agricultural Research Council (NARC), International Maize and Wheat Improvement Centre (CIMMYT) and Rice-Wheat System Research Consortium, Kathmandu, 13-22 pp.

Satyanarayan, G. 1962. Hygrophyte vegetation of Jal Kumari. Bulletin Botanical Survey India. 4(1-4):217-224.

Thapa, C.B. and P.K. Jha. 2002. Eco-phenology of weeds in paddy fields of Pokhara and Kathmandu. Ecoprint 9(1):30-41. 